\title{
PARTISIPASI MASYARAKAT SEKITAR DANAU BERATAN DALAM KONSERVASI SUMBER DAYA AIR
}

\author{
A.A. S. Dewi Rahadiani ${ }^{1}$ I G.B. Sila Dharma ${ }^{2}$, dan I N. Norken ${ }^{2}$
}

\begin{abstract}
Abstrak : Danau merupakan salah satu sumber daya air permukaan di Pulau Bali yang menunjang kegiatan sosial ekonomi masyarakat. Meningkatnya aktivitas perekonomian menimbulkan berbagai pencemaran dan penurunan fungsi Danau Beratan. Hal ini tidak lepas dari campur tangan masyarakat yang ada di sekitar danau, sehingga upaya konservasi pun membutuhkan partisipasi masyarakat yang bermukim di sekitar danau. Pemikiran ini dilandasi bahwa keberhasilan konservasi sumber daya air, tidak saja tergantung pada pemerintah, tetapi keterlibatan masyarakat juga menjadi kuncinya. Penelitian ini bertujuan untuk mengidentifikasi dan menganalisis partisipasi masyarakat sekitar Danau Beratan dalam konservasi sumber daya air. Jumlah sampel yang digunakan dalam penelitian ini sebanyak 98 responden yang diambil secara purposive sampling pada Dusun Kembangmerta, Dusun Candikuning I dan Dusun Candikuning II, yang letaknya paling dekat dengan kawasan Danau Beratan dan sebagian besar penduduknya menggunakan air Danau Beratan untuk kebutuhan sehari-hari. Partisipasi masyarakat dibagi dalam dua kategori yaitu partisipasi kurang dan partisipasi baik yang dihitung berdasarkan skala likert. Sedangkan pengaruh variabel bebas umur $\left(\mathrm{X}_{1}\right)$, pendidikan $\left(\mathrm{X}_{2}\right)$, pendapatan $\left(\mathrm{X}_{3}\right)$, lama tinggal $\left(\mathrm{X}_{4}\right)$ dan persepsi $\left(\mathrm{X}_{5}\right)$ terhadap variabel terikat partisipasi yang dihitung menggunakan analisis diskriminan. Hasil penelitian menunjukkan bahwa partisipasi masyarakat sekitar Danau Beratan dalam konservasi sumber daya air sudah baik. Variabel yang membedakan adalah Umur responden dan Pendapatannya
\end{abstract}

Kata kunci: partisipasi masyarakat, Danau Beratan, konservasi, sumber daya air

\section{THE PARTICIPATION OF COMMUNITY SURROUNDING THE LAKE BERATAN IN THE CONSERVATION OF WATER RESOURCES}

Abstract : Lakes are one of the surface water resources in Bali Island which supports the socioeconomic activities of the community. The growing economic activities either in the tourism or agricultural sector have their effects on the emergence of various problems such as the environmental pollution, shallowness of lakes and erosions. The emergence of various pollutions and the decreased functions of the Lake Beratan is not separable from the intervention of the community living surrounding the lake so that the conservation efforts need the community participation living surrounding the lake. This is based on the idea that the success of the conservation of water resources does not only depend upon the government but the involvement of the community also becomes a key factor. This study aims to identify and analyze the participation of the community living surrounding the Lake Beratan in the conservation of water resources. The number of samples used in this study was 98 respondents gathered by means of purposive sampling in the village of Kembangmerta, the village of Candikuning I and Candikuning II which are located close to the area of Lake Beratan and the majority of the people there use the lake water for daily needs. The community participation is divided into two categories, less participations and good participations, calculated based on Likert scale while the effect of free variables such as age $\left(\mathrm{X}_{1}\right)$, education $\left(\mathrm{X}_{2}\right)$, income $\left(\mathrm{X}_{3}\right)$, length of living $\left(\mathrm{X}_{4}\right)$, and perception $\left(\mathrm{X}_{5}\right)$ on bond variables were calculated using discriminating analysis. The result of the study shows that the community participation surrounding Beratan Lake in conserving water resources had been good. The differentiating variables were the age of the respondents and their incomes.

Keywords: community participation, Lake Beratan, conservation, water resources.

\footnotetext{
${ }^{1}$ Alumnus Program Studi Magister Teknik Sipil, Program Pascasarjana Universitas Udayana

${ }^{2}$ Staf Pengajar Program Studi Magister Teknik Sipil, Program Pascasarjana Universitas Udayana
} 


\section{PENDAHULUAN \\ Latar Belakang}

Danau merupakan salah satu sumber daya air permukaan di Pulau Bali yang menunjang kegiatan sosial ekonomi masyarakat. Selain itu danau juga merupakan kawasan yang disucikan, dan memiliki potensi pariwisata yang sangat luar biasa. Namun disamping memiliki potensi besar dalam kehidupan masyarakat, danau juga dapat menimbulkan berbagai bencana bila tidak dijaga kelestariannya. Meningkatnya aktivitas perekonomian baik dari sektor pariwisata atau dari sektor pertanian mengakibatkan timbulnya berbagai masalah, seperti pencemaran lingkungan, pendangkalan danau dan erosi.

Danau Beratan pun tidak luput dari masalah tersebut diatas. Berbagai penelitian dilakukan oleh Pusat Regional Lingkungan Hidup Bali Nusa Tenggara untuk mengetahui kualitas air danau. Danau yang terletak di Kabupaten Tabanan ini, terindikasi tercemar limbah phosphat $(11,553 \mathrm{mg} / \mathrm{l})$ dan zat organik $(11,380 \mathrm{mg} / \mathrm{l})$. Berdasarkan standar baku kualitas air dalam Peraturan Pemerintah No. 82 Tahun 2001, kadar phosphat yang diperbolehkan adalah $2 \mathrm{mg} / 1$ sedangkan untuk zat organik adalah $10 \mathrm{mg} / \mathrm{l}$. Tingginya kadar phosphat dimungkinkan akibat pemakaian zat kimia dari pupuk yang digunakan petani di sekitar danau. Selain tercemar limbah zat kimia, Danau Beratan juga dibanjiri sampah plastik dan terjadi pendangkalan danau sebagai akibat penimbunan bekas material bangunan. Penelitian yang dilakukan oleh Bappeda Propinsi Bali tahun 2002 dan Studi Konservasi Perlindungan Danau Beratan di Kabupaten Tabanan dan Danau Tamblingan di Kabupaten Buleleng oleh Balai Wilayah Sungai Bali-Penida Direktorat Jenderal Sumber Daya Air Kementerian Pekerjaan Umum RI tahun 2012 diatas tersebut juga menyebutkan bahwa tingkat erosi yang terjadi di daerah tersebut 1,958-33,916 ton/ha/tahun dan lahan di sekitar Danau Beratan tergolong jenis tanah regosol berhumus yang ciri-cirinya tekstur lempung berpasir, struktur granulair halus, permeabilitas sangat tinggi dan infiltrasi sangat cepat serta peka erosi. Perubahan tata guna lahan dari areal hutan menjadi pemukiman juga meningkat dan disinyalir akan terus meningkat di masa yang akan datang. Lebih lanjut penelitian tersebut juga menyebutkan bahwa pencemaran oleh minyak dan lemak sebesar 14,66 mg/lt air diakibatkan oleh beroperasinya perahu bermotor di kawasan ini. Bakteri E. Coli pun telah mencemari air danau sebesar 105,33 MPN/100 ml air.

Menurut Undang-undang No. 5 tahun 1990 tentang konservasi sumber daya alam dan ekosistem, menyebutkan bahwa konservasi sumber daya alam adalah pengelolaan sumber daya alam untuk menjamin pemanfaatannya secara bijaksana serta kesinambungan ketersediaannya dengan tetap memelihara dan meningkatkan kualitas serta keanekaragamannya. Undangundang Nomor 7 tahun 2004 tentang Sumber Daya Air pasal 83 juga menyebutkan bahwa dalam menggunakan hak guna air, masyarakat pemegang hak guna air berkewajiban memperhatikan kepentingan umum yang diwujudkan melalui perannya dalam konservasi sumber daya air serta perlindungan dan pengamanan prasarana sumber daya air.

Peraturan-peraturan diatas menguatkan bahwa upaya pelibatan masyarakat setempat dalam konservasi sumber daya air menjadi sangat penting. Masyarakat tidak hanya sebagai penonton pelaksanaan pembangunan, tetapi mereka mereka harus secara aktif ikut dalam perencanaan, pelaksanaan, pengawasan dan menikmati hasil pembangunan. Tetapi pada dasarnya tidak ada jaminan bahwa suatu program akan berkelanjutan melalui partisipasi semata. Keberhasilannya juga dipengaruhi oleh beberapa faktor dari dalam dirinya seperti umur, tingkat pendidikan, tingkat pendapatan, lama tinggal dan persepsinya.

Terdapat beberapa metode yang digunakan untuk menganalisis partisipasi masyarakat, salah satunya adalah analisis diskriminan. Analisis diskriminan ini digunakan untuk mengetahui apakah terdapat perbedaan yang jelas antara faktor umur, tingkat pendidikan, tingkat pendapatan, lama tinggal pada suatu daerah dan persepsi terhadap partisipasinya dalam konservasi sumber daya air.

Dengan demikian dibutuhkan penelitian tentang konservasi sumber daya air di sekitar Danau Beratan ditinjau dari partisipasi masyarakatnya. Hal ini dilandasi oleh pemikiran bahwa keberhasilan konservasi sumber daya air, tidak saja tergantung pada pemerintah, tetapi keterlibatan masyarakat juga menjadi kuncinya. Penelitian ini juga diharapkan dapat menjadi dasar pengambilan keputusan dalam rangka kegiatan pengelolaan sumber daya air. 


\section{Tujuan Penelitian}

Tujuan dari penelitian ini adalah sebagai berikut:

1. Mengidentifikasi dan menganalisis partisipasi masyarakat sekitar Danau Beratan dalam konservasi sumber daya air.

2. Menganalisis perbedaan yang signifikan antara masyarakat sekitar Danau Beratan yang berpartisipasi baik dan yang kurang berpartisipasi dalam konservasi sumber daya air.

3. Menganalisis faktor yang signifikan menentukan perbedaan kelompok masyarakat yang berpartisipasi baik dan yang kurang berpartisipasi dalam konservasi sumber daya air?

\section{KAJIAN PUSTAKA \\ Konservasi Sumber Daya Air}

Air merupakan kebutuhan utama semua makhluk hidup. Dengan pertambahan penduduk yang sangat cepat, kebutuhan akan airpun meningkat. Namun sumber air tidak bertambah bahkan cenderung berkurang akibat pengelolaan yang salah. Kerusakan lingkungan dan pencemaran air yang meningkat serta jaminan akan tersedianya air tawar yang bersih telah berkembang menjadi isu global. Untuk itu diperlukan pengelolaan sumber daya air yang lebih baik.

Pengelolaan air dalam suatu DAS harus memperhitungkan semua keperluan rumah tangga manusia, industri, pertanian, penyangga lingkungan (seperti danau, rawa) dan lingkungan hidup hewan dan tumbuhan (Arsyad, 2012).

Konservasi air adalah upaya menggunakan air yang sampai di permukaan bumi untuk keperluan manusia secara efisien dan memenuhi berbagai keperluan lingkungan. Konservasi air meliputi dua bagian, yaitu konservasi sumber daya air (water resources conservation), dan konservasi penyediaan air (water supply conservation). Konservasi sumberdaya air meliputi metode penyimpanan dan alokasi air secara efisien. Konservasi penyediaan air meliputi pendistribusian dengan kebocoran yang minimal (distribution with minimal loss) dan konsumsi tanpa ada yang terbuang (consumption without wastage) (Arsyad, 2012).

Beberapa faktor yang menyebabkan kendala dalam melakukan pengelolaan sumber daya air, menurut Balai Lingkungan Keairan Pusat Litbang Sumber Daya Air antara lain adalah banyaknya instansi yang terkait dalam melakukan pengelolaan DAS waduk, yaitu setiap instansi lebih mementingkan sektornya daripada konservasinya; banyaknya instansi yang terkait dalam pemanfaatan air danau atau waduk sehingga menimbulkan konflik kepentingan; perbedaan batas ekologis dan administratif, sehingga ada keengganan pemerintah tempat berlokasinya danau/waduk untuk melakukan upaya konservasi yang optimal; masih lemahnya kapasitas kemampuan instansi pengelola dalam melakukan konservasi; kurangnya pemahaman dan kesadaran, pengetahuan dan kemampuan untuk melakukan konservasi bagi penduduk yang ada disekitar DAS ataupun penduduk yang bermukim di sekitar danau/waduk.

Konservasi air ditujukan tidak hanya meningkatkan volume air, tetapi juga meningkatkan efisiensi penggunaannya, sekaligus memperbaiki kualitasnya sesuai dengan peruntukannya. Konservasi air mempunyai multi-efek, diantaranya mengurangi banjir, kekeringan dan longsor dan lain sebagainya. (Kodoatie dan Sjarief, 2010).

Sesuai dengan UU No. 7 Tahun 2004, kegiatan konservasi sumber daya air pada hakekatnya ditujukan untuk : menjaga keberlanjutan keberadaan air dan sumber air, termasuk potensi yang terkandung di dalamya, menjaga keberlanjutan kemampuan sumber daya air untuk mendukung perikehidupan manusia dan makhluk hidup lainnya, menjaga keberlanjutan kemampuan air dan sumber air untuk menyerap zat, energi dan atau komponen lain yang masuk dan dimasukkan ke dalamnya. Karena tujuannya begitu penting, dalam UU No. 7 Tahun 2004 tentang sumber daya air dalam aspek pengelolaannya, konservasi ditempatkan dalam urutan yang pertama. Bahkan ada 44 pasal dari total 100 pasal dalam UU tersebut yang menyatakan baik secara eksplisit maupun implisit hal-hal yang berkaitan dengan konservasi maupun lingkungan (Kodoatie dan Hadimuljono, 2005 dalam Kodoatie dan Sjarief, 2010).

Konservasi sumber daya air dilakukan melalui kegiatan-kegiatan (ayat(2) Pasal 20 UU Sumber Daya Air ): perlindungan dan pelestarian sumber air, pengelolaan kualitas air, pengawetan air, pengendalian pencemaran air.

Konservasi sumber daya air dilaksanakan pada sungai, danau, waduk, rawa, cekungan air tanah, sistem irigasi, daerah tangkapan 
air atau daerah aliran sungai (DAS), kawasan suaka alam, kawasan pelestarian alam, kawasan hutan dan kawasan pantai (ayat (1) pasal 25 UU Sumber Daya Air).

Dalam Suripin (2002), pendekatan dasar dalam konservasi tanah dan air adalah sebagai berikut: (1) Menyediakan penutup tanah dengan tanaman atau mulsa agar tanah terlindung dari pukulan hujan langsung; (2) Memperbaiki dan menjaga kondisi tanah agar tanah tahan terhadap penghancuran dan pengangkutan, serta meningkatkan kapasitas infiltrasi; (3) Mengatur aliran permukaan sedemikian rupa sehingga mengalir dengan energi yang tidak merusak; Meningkatkan efisiensi penggunaan air; (5) Menjaga kualitas air; (6) Mendaur ulang air.

Sungai, waduk dan danau merupakan sumber air yang sangat penting fungsinya dalam pemenuhan kebutuhan masyarakat dan meningkatkan pembangunan nasional, sehingga dalam rangka pemanfaatan dan pelestariannya dipandang perlu melakukan pengaturan mengenai sumber air tersebut yang meliputi perlindungan, pengembangan, penggunaan dan pengendalian dengan Peraturan Pemerintah (PP), Waluya (2010).

\section{Partisipasi Masyarakat dalam Konservasi Sumber Daya Air \\ Pengertian Partisipasi Masyarakat}

Partisipasi sebagai salah satu elemen pembangunan merupakan proses adaptasi masyarakat terhadap perubahan yang sedang berjalan. Dengan demikian partisipasi mempunyai posisi yang penting dalam pembangunan. Sumodiningrat menambahkan, bahwa prasyarat yang harus terdapat dalam proses pembangunan berkelanjutan adalah dengan mengikutsertakan semua anggota masyarakat/rakyat dalam setiap tahap pembangunan (Sumodiningrat,1988 dalam Murtiyanto, 2011).

Keberhasilan pengelolaan konservasi sumberdaya alam hayati dan ekosistemnya, tidak saja menjadi tanggung jawab pemerintah akan tetapi juga diperlukan peran serta masyarakat, seperti yang disebutkan dalam Undang-undang No. 5 tahun 1990 tentang konservasi sumber daya alam hayati dan ekosistemnya (UUKH) Pasal 37 menyebutkan bahwa:

(1) Peran serta rakyat dalam konservasi sumber daya alam hayati dan ekosistemnya diarahkan dan digerakkan oleh pemerintah melalui berbagai kegiatan yang berdaya guna dan berhasil guna.

(2) Dalam mengembangkan peran serta rakyat sebagaimana dimaksud dalam ayat (1). Pemerintah menumbuhkan dan meningkatkan sadar konservasi sumber daya alam hayati dan ekosistemnya di kalangan rakyat melalui pendidikan dan penyuluhan.

(3) Ketentuan lebih lanjut sebagaimana dimaksud dalam ayat (1) dan ayat (2) diatur dengan Peraturan Pemerintah.

Selanjutnya dalam penjelasan Pasal 37 ayat (1) UUKH, menyebutkan bahwa peran serta rakyat dapat berupa perorangan dan kelompok masyarakat baik yang berorganisasi maupun tidak. Agar rakyat dapat berperan secara aktif dalam kegiatan konservasi sumber daya alam hayati dan ekosistemnya, maka melalui kegiatan penyuluhan, pemerintah perlu mengarahkan dan menggerakkan rakyat dengan mengikutsertakan kelompok-kelompok masyarakat kemudian ayat (2) menyebutkan bahwa, dalam upaya menumbuhkan dan meningkatkan sadar konservasi di kalangan rakyat, maka perlu ditanamkan pengertian dan motivasi tentang konservasi sejak dini melalui jalur pendidikan sekolah dan luar sekolah.

Faktor-faktor yang Mempengaruhi Partisipasi Masyarakat

Menurut Sastroputro (1998) dalam Saptorini (2003), faktor yang dapat mempengaruhi partisipasi masyarakat adalah keadaan sosial masyarakat, kegiatan program pembangunan dan keadaan alam sekitar. Keadaan sosial masyarakat meliputi pendidikan, pendapatan, kebiasaan dan kedudukan sosial dalam sistem sosial. Kegiatan program pembangunan merupakan kegiatan yang direncanakan dan dikendalikan oleh pemerintah yang dapat berupa organisasi masyarakat dan tindakan kebijaksanaan. Sedangkan alam sekitar merupakan faktor fisik atau keadaan geografis daerah yang ada pada lingkungan tempat tinggal masyarakat setempat. Tokoh masyarakat, pemimpin adat, tokoh agama adalah merupakan komponen yang juga berpengaruh dalam menggerakkan masyarakat untuk berpartisipasi dalam suatu kegiatan

Menurut penelitian yang dilakukan Muba (2005), pelaksanaan kegiatan proyek masih banyak yang mengalami kegagalan karena pelaksanaannya sebagian besar masih pendekatan dari atas (top-down approach), kurang melibatkan masyarakat dalam 
perencanaannya sehingga masyarakat kurang berpartisipasi dalam menjaga, memelihara, dan mendukung pelaksanaan kegiatan. Agar pelaksanaan kegiatan konservasi lingkungan berjalan lebih lancar maka sejak perencanaan masyarakat ikut dilibatkan yakni dengan melaksanakan PRA (Participative Rural Appraisal).

Pendapatan masyarakat, kemiskinan dan tingkat pendidikan seseorang juga mempengaruhi partisipasi masyarakat dalam mengelola lingkungan hidup. Hal ini terungkap pada penelitian yang dilakukan Erwiantono (2006). Lebih jauh diungkapkan pula bahwa ambisi seseorang untuk mencapai tujuan tertentu juga mempunyai hubungan dengan tingkat ekonomi keluarganya. Jadi dengan tingkat pendapatan yang lebih baik atau tinggi dapat mendorong seseorang berpartisipasi lebih baik pula.

\section{Analisis Diskriminan}

Analisis diskriminan merupakan suatu teknik analisis yang dianggap tepat guna mencari hubungan antara variabel terikat yang bersifat kategorial dan variabel bebas yang terukur. Teknik analisis ini memiliki kemampuan untuk memprediksi dan menjelaskan hubungan atau pengaruh yang terjadi. Dengan analisis diskriminan dapat ditentukan variabel prediktor mana yang mempunyai kontribusi paling besar dalam membedakan kelompok-kelompok di dalamnya.

\section{METODE PENELITIAN}

\section{Lokasi Penelitian}

Penelitian ini dilakukan di sekitar Danau Beratan yaitu Dusun Candikuning I, Dusun Candikuning II dan Dusun Kembangmerta yang termasuk ke dalam wilayah Desa Candikuning, Kecamatan Baturiti, Kabupaten Tabanan.

\section{Jenis dan Sumber Data}

Data primer diperoleh dengan melakukan lapangan baik dari pengamatan observasi secara fisik ataupun wawancara terhadap responden terpilih.

Data sekunder diperoleh dengan melakukan survei institusional.

\section{Metode Penentuan Sampel}

Pengambilan sampel secara purposive sampling dengan jumlah responden sebanyak 98 responden

Dan besarnya sampel untuk masingmasing dusun adalah sebagai berikut:

Dusun Kembangmerta $=31$ orang, Dusun Candikuning I $=24$ orang, Dusun Candikuning II $=43$ orang.

\section{Variabel dan Instrumen Penelitian}

Variabel terikat berupa partisipasi masyarakat dalam dua kategori yaitu partisipasi kurang dan partisipasi baik, yang diukur dari keikutsertaan masyarakat dalam kegiatan konservasi sumber daya air, baik dalam kegiatan fisik (perencanaan, pelaksanaan, pemeliharaan dan evaluasi) maupun kegiatan non fisik (berupa masukan ide-ide yang berkaitan dengan kegiatan tersebut).

Variabel bebas yang terdiri dari: umur, tingkat pendidikan, pendapatan, lama tinggal dan persepsi tentang konservasi sumber daya air.

Instrumen yang digunakan dalam penelitian ini adalah angket (kuisioner) tertutup dan angket semi terbuka.

\section{Teknik Analisis Data}

Dalam studi ini, teknik analisis data dilakukan secara deskriptif kualitatif dengan analisis menggunakan skala likert yang kemudian dihitung dengan analisis diskriminan. Partisipasi masyarakat dalam konservasi sumber daya air akan dikategorikan dalam dua kelompok kategori, yakni yang berpartisipasi baik dan yang berpartisipasi kurang, dilakukan berdasarkan jawaban atas pertanyaan yang berkaitan dengan partisipasi yang menghasilkan rentang skor 10 - 50. Responden dengan skor 10-30 akan dikelompokkan dalam kategori berpartisipasi kurang, sedangkan yang memiliki skor 31-50 dikelompokkan dalam kategori berpartisipasi baik. Setelah dilakukan pengelompokkan, dilakukan analisis diskriminan untuk mengetahui faktor dominan yang mempengaruhi partisipasi masyarakat sekitar Danau Beratan terhadap konservasi sumber daya air.

Setelah dilakukan pengkategorian menggunakan skala likert maka dilakukan analisis diskriminan.

Proses dasar dari analisis diskriminan adalah sebagai berikut:

1. Memilah variabel-variabel menjadi variabel terikat dan variabel bebas.

Variabel terikat (Z) adalah data kategorikal yaitu: Partisipasi kurang (kode 0), partisipasi baik (kode 1).

Variabel bebas yaitu: umur $\left(\mathrm{X}_{1}\right)$, pendidikan $\left(\mathrm{X}_{2}\right)$, pendapatan $\left(\mathrm{X}_{3}\right)$, lama tinggal $\left(\mathrm{X}_{4}\right)$ dan persepsi $\left(\mathrm{X}_{5}\right)$.

2. Menentukan metode untuk membuat fungsi diskriminan. Penelitian ini menggunakan metode step-wise estimation.

3. Membuat fungsi diskriminan.

4. Uji Validasi fungsi diskriminan 
Dalam penelitian ini karena variabel terikatnya dua, maka digunakan teknik analisis diskriminan dua kelompok. $Z_{\mathrm{jk}}=\mathrm{a}+$ $\mathrm{W}_{1} \mathrm{X}_{1 \mathrm{k}}+\mathrm{W}_{2} \mathrm{X}_{2 \mathrm{k}}+\ldots \ldots+\mathrm{W}_{\mathrm{n}} \mathrm{X}_{\mathrm{nk}}$

Dimana:

$$
\begin{aligned}
\mathrm{Z}_{\mathrm{jk}}= & \mathrm{Z} \text { skor diskriminan dari fungsi } \\
& \text { diskriminan } \mathrm{j} \text { untuk obyek } \mathrm{K}
\end{aligned}
$$

\section{Pengujian Validitas dan Reliabilitas Instrumen Penelitian}

Untuk menguji validitas alat ukur, digunakan rumus Pearson Product Moment.

Pengujian reliabilitas instrumen dalam penelitian ini menggunakan metode belah dua (split half) dan Spearman Brown.

\section{HASIL DAN PEMBAHASAN Pembahasan Hasil Penelitian}

Partisipasi dapat diartikan sebagai keikutsertaan atau keterlibatan masyarakat sekitar Danau Beratan dalam kegiatan konservasi sumber daya air. Partisipasi masyarakat tersebut diukur dari indikator mulai tahap perencanaan, pelaksanaan, evaluasi dan pemahaman tentang konservasi sumber daya air

Terhadap pertanyaan mengenai keikutsertaan dalam kegiatan perencanaan konservasi sumber daya air yang digerakkan pemerintah/ LSM, 28 responden $(28,57 \%)$ menyatakan sangat setuju mengikuti kegiatan perencanaan konservasi sumber daya air,13 responden $(13,13 \%)$ menyatakan setuju, 35 responden $(35,35 \%)$ menyatakan netral. Hanya 18 responden menyatakan tidak setuju dan 5 responden menyatakan sangat tidak setuju. Pernyataan responden ini disebabkan karena belum adanya pemerataan sosialisasi kegiatan perencanaan konservasi sumber daya air yang dilakukan oleh pemerintah kepada masyarakat sekitar danau, walaupun kegiatan-kegiatan ini sudah dilaksanakan seperti kegiatan perencanaan konservasi sumber daya air oleh Balai Wilayah Sungai Bali-Penida tahun 2012.

Mengenai keikutsertaan dalam kegiatan pelaksanaan konservasi sumber daya air yang digerakkan atau difasilitasi pemerintah atau LSM; 46,94 \% responden menyatakan setuju ikut serta dalam kegiatan pelaksanaan konservasi sumber daya air

Responden yang menyatakan sangat tidak setuju mengikuti kegiatan evaluasi konservasi sumber daya air yaitu sebanyak $40,82 \%$ yang digerakkan atau difasilitasi pemerintah atau LSM. Hal ini disebabkan belum meratanya sosialisasi yang diadakan pemerintah mengenai kegiatan konservasi sumber daya air, sehingga responden merasa belum pernah terlaksana kegiatan konservasi sumber daya air. Oleh sebab itu mereka beranggapan bahwa tidak ada kegiatan yang harus dievaluasi.

Mengenai pertanyaan terhadap persetujuan untuk melakukan konservasi sumber daya air dilakukan atas kehendak sendiri 40,40 \% responden menyatakan setuju. Hal ini menggambarkan bahwa masyarakat sekitar Danau Beratan memiliki keinginan yang kuat untuk menjaga lingkungannnya agar terhindar dari segala kerusakan. Peran aparat pemerintah untuk memberikan berbagai penyuluhan tentang konservasi sumber daya air yang benar menjadi kunci utama agar partisipasi masyarakat di daerah ini dapat terus ditingkatkan.

Empat puluh sembilan responden $(49,49 \%)$ menyatakan sangat tidak setuju bahwa telah dilakukan bentuk-bentuk kegiatan konservasi sumber daya air di desa ini. Hal ini didasari oleh pemahaman masyarakat bahwa yang dimaksud dengan kegiatan konservasi sumber daya air adalah kegiatan-kegiatan fisik semata. Kegiatan perencanaan yang telah dilakukan di desa ini adalah Studi Konservasi Perlindungan Danau Beratan di Kabupaten Tabanan dan Danau Tamblingan di Kabupaten Buleleng yang meliputi perencanaan pengelolaan daerah tangkapan hujan (watershed management), pengelolaan kuantitas air (water quantity management), pengelolaan kualitas air (water quality management), pengendalian banjir (flood control management) dan distribusinya (flood distribution management) dan pengelolaan lingkungan danau (lake environment management) yang diprakarsai oleh Balai Wilayah Sungai Bali-Penida pada tahun 2002.

Kegiatan konservasi sumber daya air perlu dilakukan dengan pengawasan aparat berwenang, $63 \%$ responden mendukung pernyataan ini. Pemahaman masyarakat ini perlu diluruskan, karena kegiatan konservasi sumber daya air sebaiknya dilakukan dengan kehendak sendiri walaupun tidak ada pengawasan dari aparat berwenang (Gambar 4.6).

Konservasi sumber daya air harus didanai pemerintah, $55 \%$ responden menyatakan setuju agar konservasi sumber daya air didanai pemerintah. Hal ini 
berkaitan erat dengan pendapatan responden yang sebagian besar berkisar antara $\mathrm{Rp}$ $500.00,00$ sampai dengan Rp 1.000.000,00 per bulan. Jika kebutuhan pokok seseorang belum terpenuhi maka tidak mungkin orang tersebut bisa dilibatkan untuk berpartisipasi dalam suatu kegiatan.

Pembentukan kelompok penghijauan mendapat tanggapan yang sangat positif dari responden. Lebih dari $50 \%$ responden menyatakan setuju bila dibentuk kelompokkelompok penghijauan. Peran pemerintah sangat dibutuhkan sebagai fasilitator agar kelompok penghijauan ini dapat terwujud dan sebagai ujung tombak dalam pelaksanaan konservasi sumber daya air di daerah ini .

Bila dilakukan konservasi di sekitar Danau Beratan, hampir seluruh responden menanggapi positif hal tersebut, responden menyatakan setuju $(66,67 \%)$ dan sangat setuju $(25,25 \%)$.

Persepsi masyarakat bahwa air bernilai ekonomis sehingga penggunaannya harus dihemat, sangat baik. Karena dari persepsi masyarakat ini akan menentukan partisipasinya dalam konservasi sumber daya air .

Tetapi dari 98 responden, 26,26\% menyatakan bahwa air Danau Beratan sudah tercemar limbah dan perlu dilakukan pembatasan-pembatasan tentang ijin-ijin pengoperasian kegiatan wisata. Persepsi masyarakat sekitar Danau Beratan yang masih beranggapan bahwa kualitas Danau Beratan masih baik dan belum mengalami pencemaran, akan menyebabkan kurangnya kewaspadaan untuk terus meningkatkan partisipasi dalam pengendalian pencemaran air.

Pernyataan-pernyataan responden tersebut ditabulasi kemudian dihitung menggunakan skala likert. Dari perhitungan menggunakan skala likert, diperoleh hasil bahwa responden yang termasuk berkategori partisipasi baik adalah sebanyak 62 orang atau 63,26\%. Dari 62 responden yang berkategori berpartisipasi baik, 75\% memahami bahwa konservasi sumber daya air sebagai cara untuk menjaga sumber air agar tidak tercemar dan menggunakan air secara efisien. Namun demikian, seluruh responden belum memahami air limbah yang diresapkan langsung ke tanah pun akan membuat air tanah tercemar. Lebih lanjut dibutuhkan peran pemerintah untuk mengatasinya dengan memberikan lebih banyak penyuluhan.
Sedangkan yang berkategori partisipasi kurang yaitu sebanyak 36 orang atau $36,73 \%$. Dari data yang diperoleh, 66,66\% responden yang termasuk kategori berpartisipasi kurang adalah yang tidak mengetahui apa dan mengapa harus dilakukan konservasi sumber daya air.

Kurangnya penyuluhan yang diadakan oleh pemerintah tentang pentingnya konservasi sumber daya air merupakan salah satu penyebab masih tingginya angka masyarakat yang kurang berpartisipasi dalam konservasi sumber daya air. Hanya $13,13 \%$ dari 98 responden yang menyatakan bahwa pengetahuan tentang konservasi sumber daya air mereka dapatkan dari penyuluhan yang dilakukan oleh pemerintah. Sisanya sebanyak $86,87 \%$ mendapatkan pengetahuan tentang konservasi sumber daya air melalui media massa (televisi, majalah, koran, dll).

Berdasarkan analisis dapat dijelaskan bahwa ada keterkaitan antara umur dan pendapatan dengan partisipasi masyarakat. Sedangkan faktor tingkat pendidikan formal, lama tinggal dan persepsi masyarakat tidak mempengaruhi kedua kelompok partisipasi masyarakat.

Dari analisis diskriminan didapat hasil bahwa ada perbedaan yang jelas antara responden yang berpartisipasi baik dengan responden yang berpartisipasi kurang dalam konservasi sumber daya air. Variabel yang membedakan adalah Umur responden dan Pendapatannya. Fungsi diskriminan yang terbentuk adalah Score $=0,472-0,069 \mathrm{X}_{1}+$ $0,951 \mathrm{X}_{3}$, yang menunjukkan bahwa variabel-variabel bebas yang signifikan menentukan perbedaan kelompok masyarakat berpartisipasi kurang dan berpartisipasi baik adalah $\mathrm{X}_{1}$ (Umur) dan $\mathrm{X}_{3}$ (Pendapatan). Berdasarkan tanda dari koefisien variabel, terlihat bahwa variabel umur bertanda negatif. Hal ini berarti variabel tersebut cenderung menurunkan skor fungsi disriminan, apabila variabel pendapatan konstan. Lain halnya dengan variabel pendapatan yang bertanda positif, yang berarti variabel pendapatan akan meningkatkan skor fungsi diskriminan. Dengan kata lain semakin tinggi pendapatan seseorang maka cenderung meningkatkan partisipasinya dalam konservasi sumber daya air. 


\section{SIMPULAN DAN SARAN \\ Simpulan}

Berdasarkan hasil penelitian dan analisis yang dilakukan dapat disimpulkan beberapa hal sebagai berikut:

1. Partisipasi masyarakat dalam konservasi sumber daya air di sekitar Danau Beratan Kabupaten Tabanan sudah baik. Hal ini terlihat dari prosentase masyarakat yang berkategori partisipasi baik sebanyak $63,26 \%$. Masyarakat yang berada di sekitar Danau Beratan sudah memahami perlindungan dan pelestarian sumber daya air serta pengendalian pencemaran air.

2. Terdapat perbedaan yang signifikan antara masyarakat yang berpartisipasi baik dengan masyarakat yang berpartisipasi kurang dalam konservasi sumber daya air yang ditunjukkan dengan angka validasi $62,2 \%$. Variabel yang membedakan adalah Umur responden dan Pendapatannya.

3. Dari fungsi diskriminan yang terbentuk menunjukkan bahwa variabel-variabel bebas yang signifikan menentukan perbedaan kelompok masyarakat berpartisipasi kurang dan berpartisipasi baik adalah $\mathrm{X}_{1}$ (Umur) dan $\mathrm{X}_{3}$ (Pendapatan). Berdasarkan tanda dari koefisien variabel, terlihat bahwa variabel umur bertanda negatif. Hal ini berarti variabel tersebut cenderung menurunkan skor fungsi disriminan, apabila variabel pendapatan konstan. Lain halnya dengan variabel pendapatan yang bertanda positif, yang berarti variabel pendapatan akan meningkatkan skor fungsi diskriminan. Dengan kata lain semakin tinggi pendapatan seseorang maka cenderung meningkatkan partisipasinya dalam konservasi sumber daya air.

\section{Saran}

1. Memasukkan pengetahuan dasar tentang konservasi sumber daya air ke dalam kurikulum pendidikan formal.

2. Lebih meningkatkan sosialisasi berbagai kegiatan yang akan dilakukan menyangkut konservasi sumber daya air kepada seluruh penduduk desa, agar semakin lama penduduk tersebut tinggal di Desa Candikuning semakin tinggi partisipasinya dalam konservasi sumber daya air.

3. Memberikan berbagai penyuluhan kepada seluruh penduduk agar memiliki persepsi bahwa konservasi sumber daya air perlu selalu dilakukan untuk menjaga dan memelihara sumber daya air di sekitar Danau Beratan. Penyuluhan ini bsa dilakukan melalui karang taruna, perkumpulan keagamaan, dan kegiatankegiatan non formal lainnya.

4. Penelitian lanjutan tentang peran serta stakeholder dalam konservasi sumber daya air di sekitar Danau Beratan perlu dilakukan, mengingat kawasan tersebut merupakan kawasan wisata yang rentan akan kerusakan yang disebabkan oleh orang-orang di luar kawasan tersebut.

\section{DAFTAR PUSTAKA}

Anonim. 2009. Pengelolaan Danau dan Waduk di Indonesia. Balai Lingkungan Keairan Pusat Litbang Sumber Daya Air.

Anonim. 2012. Persepsi-pengertian-definisidan-faktor-yang-mempengaruhi:

Available from: URL http://www.duniapsikologi.com/

Anonim. 2012. Study Konservasi Perlindungan Danau Beratan di Kabupaten Tabanan dan Danau Tamblingan di Kabupaten Buleleng. Laporan Akhir: Kementrian PU, Direktorat Jenderal SDA, Balai Wilayah Sungai Bali-Penida.

Arsyad, S. 2012. Konservasi Tanah dan Air dalam Penyelamatan Sumber Daya Air.Yayasan Pustaka Obor Indonesia.

Badan Pusat Statistik. 2012. Kecamatan Baturiti Dalam Angka, 2012.

Erwiantono. 2006. Kajian Tingkat Partisipasi Masyarakat dalam Pengelolaan Ekosistem Mangrove di Kawasan Teluk Pangpang-Banyuwangi. EPP. Vol. 3 No. 1.

Kodoatie, R.J \& Sjarief,R. 2010. Tata Ruang Air. Andi Yogyakarta.

Kodoatie,R.J \& Sjarief, R. 2005. Pengelolaan Sumber Daya Air Terpadu. Andi Yogyakarta.

Manumudhita I Nengah, 2002. Penelitian Perubahan Tata Guna Tanah Di Wilayah Sekitar Danau Beratan Kabupaten Dati II Tabanan: BAPPEDA Propinsi Bali.

Morrisan, M A. 2012. Metode Penelitian Survei. Jakarta. Kencana Prenada Media.

Murtiyanto,N. 2011. Partisipasi Masyarakat (Teori Ringkas). Available from: URL

Pantja S.V.R. I, 2008. Faktor-faktor yang mempengaruhi Persepsi Masyarakat terhadap Kegiatan Konservasi Sumber Daya Alam. Jurnal Fakultas Pertanian Universitas Tidar Magelang Vol:30 No. 2: $60-82$. 
Riduwan. 2008. Metode dan Teknik Menyusun Tesis. Bandung. Alfabeta.

Safei, L. O. M, 2005. “ Kajian Partisipasi Masyarakat terhadap Pelestarian Hutan Mangrove (Studi kasus : Desa Marobo Kecamatan Bone dan Desa Labulu-bulu Kecamatan Parigi Kabupaten Muna Propinsi Sulawesi Tenggara” (tesis). Bogor: Institut Pertanian Bogor.

Santoso, S. 2012. Aplikasi SPSS pada Statistik Multivariat. Jakarta. Gramedia.

Saptorini, 2003. "Persepsi dan Partisipasi Masyarakat dalam Pelaksanaan Konservasi Hutan Mangrove di Kecamatan Sayung Kabupaten Demak" (tesis). Semarang : Universitas Diponegoro.

Suripin, 2002. Pelestarian Sumber Daya Tanah dan Air. Yogyakarta. Andi.

Triwanto, J. 2012. Konservasi Lahan Hutan dan pengelolaan Daerah Aliran Sungai:UMM Press.

Waluya, J. 2010. Pengelolaan Sungai, Danau dan Waduk untuk konservasi sumber daya air. Region Vol: II No. 2. 